UDC 378.147:[37.011.3-051:91]

DOI: $10.31470 / 2415-3729-2018-8-45-59$

\title{
Organizational and Functional Structure of the Future Geography Teachers' Research Activities
}

\author{
Olena Zavalniuk \\ Candidate for a degree of Doctor of Philosophy in Pedagogy (PhD), \\ Department of Pedagogy and Methods of Technological Education \\ Kryvyi Rih State Pedagogical University \\ $\triangle 54$, Haharina Ave., Kryvyi Rih, Dnipropetrovsk region, \\ Ukraine, 50000 \\ E-mail: helav68@gmail.com \\ ORCID: 0000-0001-6093-732X
}

Date of receipt of the article: August 01, 2018 Article accepted for publication: November 25, 2018

\section{Організаційно-функціональна структура науково- дослідницької діяльності майбутніх учителів географії}

\section{Олена Сергіївна Завальнюк}

здобувач кафедри педагогіки та методики технологічної освіти, Криворізький державний педагогічний університет, $\checkmark$ просп. Гагаріна, 54, м. Кривий Ріг, Дніпропетровська обл., Україна, 50086

Дата надходження статті: 01 серпня 2018 р. Стаття прийнята до друку: 25 листопада 2018 р.

\section{Abstract}

The content and purpose of the future geography teachers' research activities are considered, its functional structure is investigated in the article. It was determined that the future teachers' research activity is a dynamic system object, which can be represented in the form of hierarchically set levels of the organization, differing in goals, 
methods of scientific management and the number of participants involved in this activity.

It is defined that the foundation of the system is the subsystem of students' study and research activities, over which the six levels of organization are built. They are: 1) the level of primary students' scientific associations around the chair topics, 2) the level of the university's structural unit, 3) the level of the university, 4) the regional level, 5) the all-Ukrainian level, 6) the international level. Each of them has its own specifics and corresponds to the tasks of future geography teachers' professional preparation. For example, the last one, the sixth level is characterized by the close interaction of the higher education institution with foreign educational institutionspartners and even with associations, international foundations; many domestic universities have experience in organizing joint students' scientific conferences, academic internships and foreign students' practices, especially if nowadays students' publications, indexed in international science-centered bases, are more and more emphasized on, the competitions of scientific students' projects, grant and framework programs with the participation of young scientists become more and more important.

The author made a conclusion that this system is open and interconnected with other social systems. The main purpose of its functioning is the talented young people' identifying and involving into research activities, ensuring the continuity of higher education scientists generations, creating a university-wide scientific space; increasing of students' grant and publication activity, preparing them for innovative activity, expanding and developing of professional communications between students at the scientific level, proving the development of students' self-governance and leadership in the scientific sphere, and the development of international professional cooperation for scientists, teachers, students, practitioners. In author's opinion, realization of these ideas and other actions will enable the transition of the system of future geography teachers' professional training to a qualitatively new level.

Key words: students' research activities, the content of future geography teachers' professional preparation, pedagogical system, the research activities organization. 


\section{References}

1. Vinnyk, M. O. (2016). Innovatsiini pidkhody do orhanizatsii naukovo-doslidnytskoi diialnosti maibutnikh inzheneriv-prohramistiv [Innovative approaches to the organization of research activities of future engineer programmers]. Nauchnyie trudyi SWorld - SWorld scientific papers. Ivanovo: Iz-vo OOO «Nauchnyiy mir», 2 (43), 5256 [in Ukrainian].

2. Dyachek, T. P. (2003). Nauchno-issledovatelskaya deyatelnost kak sredstvo integratsii universiteta $\mathrm{V}$ mirovoe obrazovatelnoe prostranstvo [Research activities as a means of university's integration into the world educational space]. Proceedings of the International Conference «University as a System-Forming Factor of the Region and its Management Model». Tambov. Retrieved from http://socio.tamb.ru/6.htm [in Russian].

3. Yaroshenko, O. H. (Ed.) (2016). Kontseptsiia ta metodolohiia realizatsii naukovo-doslidnytskoi diialnosti subiektiv navchalno-vykhovnoho protsesu universytetiv [Conception and Methodology of Scientific and Research Activities for the Subjects of Universities Educational Process]. Kyiv : Instytut vyshchoi osvity NAPN Ukrainy [in Ukrainian].

4. Lavrentieva, O. O. (2014). Rozvytok metodolohichnoi kultury maibutnoho vchytelia pryrodnychykh dystsyplin u protsesi profesiinoi pidhotovky: teoretyko-metodychnyi aspekt [The future sciences teachers methodological culture development in the course of their professional training: the theoretical-methodical aspect]. Kyiv: KNT [in Ukrainian].

5. Miier, T. I. (2017). Dydaktychni zasady orhanizatsii navchalno-doslidnytskoi diialnosti molodshykh shkoliariv [The didactic principles of primary school students academic and research activity arrangement]. Extended abstract of Doctors thesis. Kyiv : In-t pedahohiky [in Ukrainian].

6. Hryshchenko, M. (Ed.) (2016). Nova ukrainska shkola: Kontseptualni zasady reformuvannia serednoi shkoly [New Ukrainian School: Conceptual Principles for Reforming the Secondary School]. Retrieved from https:/www.kmu.gov.ua/storage/app/media/reforms/ ukrainska-shkola-compressed.pdf [in Ukrainian]. 
7. Stromov V. Yu. \& Syisoev P. V. (2017) Model organizatsii nauchno-issledovatelskoy deyatelnosti studentov $\mathrm{v}$ vuze [The model of students' research activities organization in a higher educational establishment]. Vyisshee obrazovanie segodnya - Higher education today, 10, 75-82 [in Russian].

8. Topuzov, O. M., Samoilenko, V. M. \& Vishnikina, L. P. (2012). Zahalna metodyka navchannia heohrafii [General Methodology of Geography Teaching]. Kyiv : DNVP «Kartohrafiia» [in Ukrainian].

\section{Ветуп}

Науково-дослідницька діяльність студентів, як вагомий складник професійної освіти, має суттєве значення для якісної підготовки майбутніх учителів географії. У вітчизняних та зарубіжних університетах, ще від часів їх започаткування, студентські наукові дослідження завжди були й залишаються пріоритетним напрямом роботи професорсько-викладацького складу. Фахівці випускових кафедр географічних факультетів у співпраці зі студентами проводять свої дослідження в межах наукових шкіл, кафедральних тем, реалізовують держконтракти, держбюджетні, договірні, грантові й проектні роботи. Експериментальне підгрунтя географічних досліджень забезпечують зібрані студентами під керівництвом викладачів в умовах польових практик і навчальних екскурсій фактичні дані й матеріали, а також статистичні показники, отримані 3 джерел географічної інформації (Топузов, Самойленко, \& Вішнікіна, 2012). Результати науководослідницької діяльності студентів публікуються й доповідаються на студентських наукових конференціях регіонального, всеукраїнського й міжнародного рівнів, стають основою курсових і кваліфікаційних досліджень.

Передовий педагогічний досвід свідчить про те, що залучення студентів до науково-дослідницької діяльності вже починаючи з молодших курсів, а то й зі шкільної лави в межах предметних гуртків та партнерської взаємодії із закладами загальної середньої освіти, уможливлює не лише грунтовну підготовку майбутніх учителів, а й сприяє якісному оновленню 
науково-педагогічних кадрів університетів. Саме учасники наукових експедицій, наукових гуртків i географічних клубів i складають головний науковий потенціал фахових кафедр, $\epsilon$ резервом для навчання на третьому освітньо-науковому рівні підготовки докторів філософії (Лаврентьєва, 2014).

Водночас, випускники, які пройшли таку наукову підготовку, 3 успіхом працюють учителями географії в школі, є помітними в регіоні організаторами навчально-наукової роботи учнів 3 вивчення й охорони довкілля.

Теоретичні аспекти науково-дослідницької діяльності студентів як складного системного об'єкта досліджують Б. Андрієвський, С. Гончаренко, I. Зимня, С. Барбіна, В. Кремень, Є. Кулик, О. Курганов, В. Кушнір, О. Лаврентьєва, О. Малихін, О. Микитюк, Т. Мієр, О. Новиков, В. Семиченко, В. Сластьонін, О. Ярошенко та ін. Учені одностайні у висновках про те, що організація науково-дослідницької діяльності студентів має здійснюватися поетапно на засадах науково обгрунтованого управління (стратегічного, тактичного, оперативного) та супроводжуватися процесом безпосереднього чи опосередкованого керівництва 3 боку науково-педагогічних працівників зі створення системи всіх елементів структури досліджуваної діяльності у закладі вищої освіти (Мієр, 2017:21-22).

На державному рівні значущість науково-дослідницької діяльності студентів підкреслюється у численній кількості документів. У світлі ж Концепції «Нова українська школа» (2016), яка визначає новітні орієнтири в реформуванні системи освіти України, відзначається, що вчителі природничих дисциплін, зокрема географії, повинні забезпечувати формування в учнів компетентностей у природничих науках i технологіях, уміння вчитися впродовж життя, вони мають бути також здатні на власному прикладі заохочувати школярів до науково-дослідницької діяльності (Нова українська школа..., 2016).

Дослідниками (М. Вінник, М. Головань, Т. Голуб, П. Горкуненко, 3. Слєпкань, М. Князян, Н. Кушнаренко, Н. Пузирьова, Л. Султанова, Г. Цехмістрова, В. Шейко, А. Яновський та ін.) визначено сутність, зміст і функції наукової роботи в професійному та особистісному самовдосконаленні 
студентів; виокремлено науково-дослідницьку й науководослідну діяльності, розтлумачено відмінність між навчальнонауковою та науковою роботою студентів; сформульовано принципи i підходи, методи й технології та етапи організації різних аспектів науково-дослідницької діяльності студентів [4]. Л. Вішнікіною, Л. Зеленскою, С. Коберніком, В. Корнєєвим, М. Криловцем, В. Максаковським, О. Тімець, О. Топузовим та ін. вказано на специфічні характерологічні риси організації науково-дослідницької діяльності майбутніх учителів географії в різних видах професійної підготовки (Топузов, Самойленко, \& Вішнікіна, 2012).

Як провідну тенденцію сьогодення вчені відзначають інтеграцію науково-дослідницької діяльності закладів вищої освіти загалом і студентів зокрема в світовий освітній простір. Міжнародна інтеграція університетів та наукових установ у цій сфері має на увазі адаптацію зарубіжних моделей до умов i традицій вітчизняної національної культури, до вимог, що висуваються до фахівця із вищою освітою (Дьячек, 2003). Це зумовлює перегляд змісту системи професійної освіти майбутніх учителів географії, ii модернізацію та оновлення шляхом цілеспрямованої підготовки студентів до дослідницької діяльності на всіх рівнях.

Метою статті $є$ огляд функціональної структури науководослідницької діяльності майбутніх учителів географії, цільових настанов, специфіки керівництва на кожному з рівнів організації.

\section{Матеріал і методи дослідження}

Для проведення дослідження було використано низку методів наукового пошуку, зокрема - аналіз, синтез, узагальнення та систематизація наукової літератури.

\section{Результати та їх обговорення}

Установлено, що науково-дослідницька діяльність майбутніх учителів є динамічним системним об'єктом, який ініціює та забезпечує пошук студентами нового об'єктивного, системноорганізованого й обгрунтованого знання. За результатами функціонування такої системи студент оволодіває академічними та практичними професійно значущими знаннями, комплексом дослідницьких компетентностей, а також методологією 
наукового пошуку та досвідом здійснення наукового дослідження (Вінник, 2016:53).

Система науково-дослідницької діяльності студентів у вищій школі має охоплювати всіх учасників освітнього процесу. 3 боку закладу освіти це, передусім, науково-педагогічні працівники, студенти, куратори, аспіранти й докторанти, представники управлінських структур, науково-дослідних підрозділів університету, а також різні студентські наукові об'єднання й громади. 3 боку суспільного середовища - це ті особи чи організації, які беруть участь у формуванні соціального замовлення на майбутніх учителів географії, зокрема - соціальні партнери (туристичні, туристично-спортивні, геолого-краєзнавчі, екологічні установи), науково-дослідні організації (інститути, метеостанції, музеї, лісництва, дослідні майданчики), заклади загальної середньої освіти, відділи освіти, вчителі географії, куратори навчальної та виробничої практики. Принагідно зауважимо, що важливою тенденцією сьогодення $є$ включення до суб’єктів організації науково-дослідницької діяльності студентів представників зарубіжжя та іï вихід на міжнародний рівень організації.

Систему науково-дослідницької діяльності студентів можна представити у вигляді ієрархічно вибудованих рівнів організації, які розрізняються за цільовими настановами, способами наукового керівництва й кількістю залучених до цієї діяльності учасників (Стромов, \& Сысоев, 2017:75).

Фундаментом системи є підсистема навчально-дослідницької діяльності студентів, що здійснюється в межах вивчення всіх без винятку дисциплін навчального плану підготовки. До їх змісту контекстно включені спеціальні засоби, які сприяють розвитку дослідницьких компетентностей майбутніх учителів географії, тобто формуванню в них спеціальних методологічних знань (з методології географічних і педагогічних наук), функціональних навичок дослідження як універсального способу освоєння природи й суспільної дійсності, розвитку здібностей дослідника (активності, ініціативності, спостережливості, критичності мислення, рефлексивності), активної дослідницької позиції стосовно засвоєння змісту навчальних дисциплін на основі 
самостійно набутих, особистісно значущих й суб'єктивно нових знань (Лаврентьєва, 2014:360). Тематика і напрями навчальнодослідницької діяльності студентів диктуються змістом освітньої програми підготовки майбутніх учителів географії (Концепція та методологія..., 2016:8).

Перший ієрархічний рівень організації науководослідницької діяльності студентів складають первинні студентські наукові об'єднання - наукові гуртки, проблемні групи, лабораторії, центри, студентські клуби, що діють на базі профілюючих кафедр. Залежно від наукових і професійних інтересів, провідних напрямів діяльності кафедр, майбутніх учителів географії залучають до перших наукових досліджень у галузі педагогічних і географічних наук. Під керівництвом викладачів студенти вчаться визначати тематику й методологічний апарат дослідження - висувати мету й завдання, формулювати гіпотезу дослідження, вибирати методи та інструментарій дослідження, планувати й проводити дослідження, узагальнювати, аналізувати й інтерпретувати отримані дані, оформляти й презентувати отримані результати у вигляді тез, рефератів, статей, аналітичних оглядів, стендових доповідей, презентацій, виступів на наукових заходах (Стромов, \& Сысоев, 2017:76). Головною функцією цього структурного компонента $\epsilon$ виявлення здібних $\mathrm{i}$ талановитих студентів й подальший розвиток їх талантів та обдарувань, формування в них мотивів до професійного й наукового зростання. Досвід показує, що кількість студентів на цьому рівні є обмеженою, оскільки за своїм змістом первинні студентські наукові об'єднання виходять за межі навчальних планів і програм, потребують від учасників ретельної, наполегливої, самостійної й систематичної наукової праці. Для майбутніх учителів географії ще одним специфічним для цього рівня організації видом науково-дослідницької діяльності $\epsilon$ просвітницька, волонтерська, рекламна, туристсько-краєзнавча тощо робота серед населення. Не менш значущою в плані професійно-наукового зростання є партнерська взаємодія, до якої залучаються студенти, коли разом із талановитими школярами проводять спільні наукові дослідження по лінії МАН. У такий спосіб реалізується методичний напрям науково-дослідницької діяльності майбутніх учителів географії. 
Другий рівень організації складає рівень структурного підрозділу університету - факультету чи відокремленого підрозділу вишу - інституту. На цьому щаблі в межах наукових заходів (предметні олімпіади, конкурси творчих студентських робіт і проектів, конференції, семінари тощо) студенти різних споріднених спеціальностей мають можливість визначитися в напрямі власного наукового пошуку, осягнути рівень досліджень, що проводять вчені та аспіранти факультету або інституту, залучитися до міждисциплінарних проектів і нарешті розширити коло наукових зв'язків, реалізувати природне прагнення до комунікації на пізнавальному підгрунті. Функцією цього рівня $€$ створення студентських наукових товариств, які діють на засадах самоврядування й здійснюють керівництво науково-дослідницькою діяльністю студентів в межах структурних підрозділів, організовують заходи щодо популяризації науки та наукових досягнень молодих науковців, залучають студентів молодших курсів до наукового пошуку. Достатньо розповсюдженим напрямом науково-дослідницької діяльності студентів на рівні факультету $\epsilon$ науково-організаційна діяльність, яка охоплює видавничу справу й наукові заходи (Лаврентьєва, 2014:365). Цікавим і досить перспективним напрямом у цьому контексті $\epsilon$ факультетські конкурси наукових проектів («Віртуальна туристична фірма», «Краєзнавчий веб-квест», «Топоніміка рідного краю», «Засоби рекультивації відвалів та кар'єрів Криворіжжя», «Гідрологічні спостереження річки Інгулець на території міста Кривий Ріг», «Екологічний моніторинг території», «Географічний аналіз захворюваності району міста», «Економічні передумови формування машинобудівного комплексу регіону» тощо).

Загалом, як показує досвід, факультетські наукові товариства під керівництвом викладачів стають ініціаторами й започатковують збірники студентських наукових праць, щорічні звітні, регіональні й всеукраїнські наукові конференції, які піднімають актуальні питання в галузі географічних наук i методики викладання природничих дисциплін.

На третьому загальноуніверситетському ієрархічному рівні організації науково-дослідницької діяльності студентів має функціонувати єдиний, об'єднаний спільною метою, науковий 
простір. У такому просторі повинні бути створені можливості для популяризації студентської науки, пропаганди досягнень наукових шкіл, лабораторій i експериментальних майданчиків університету. Керівництво студентською наукою на цьому рівні здійснює загальноуніверситетське студентське наукове товариство, представники й активісти якого $є$ членами вчених рад університетів, проектних i фокус-груп дослідницького спрямування, редакційних колегій наукових періодичних видань. Разом із управлінським апаратом університету, зокрема 3 науковим відділом та студентською радою, на цьому щаблі проводяться масштабні міждисциплінарні наукові заходи (День науки, Тиждень студентської науки, фестиваль науково-технічної творчості тощо), тренінги, веб-форуми, конференції, випускаються мультидисциплінарні наукові періодичні видання студентів і молодих учених (Стромов, \& Сысоев, 2017:77).

Досвід організації єдиного наукового простору університету налічує чимало методичних знахідок. Наприклад, тематичний лекторій чи тренінг-сесія, на яких за допомогою як традиційних форм, так і платформ дистанційного навчання, молодих науковців навчають методології наукових досліджень, а провідні вчені університету знайомлять їx iз досягненнями та напрямами роботи наукових шкіл, наукових центів і лабораторій. Змістовим концентром, що координує науково-дослідницьку роботу студентів на загальноуніверситетському рівні, є веб-сайт закладу із виходом на соціальні мережі.

Система науково-дослідницької діяльності студентів $€$ відкритою системою, що перебуває у взаємозв'язку 3 іншими системами, зокрема із науковим простором регіону, в якому перебуває заклад вищої освіти. Тож, четвертий регіональний рівень організації має на увазі об'єднання студентів різних вишів за науковими інтересами й напрямами, що забезпечує імплементацію студентської науки у конкретну галузь суспільного виробництва й у практику. Для майбутніх учителів географії це означає можливість співпраці 3 провідними науковцями міста i регіону щодо проведення, 3 одного боку географічних досліджень на конкретних територіях, виробництвах і в природних зонах, а 
3 іншого - виконання педагогічних і методичних досліджень за потребами освітніх закладів (Лаврентьєва, 2014:370).

Наступний п’ятий рівень організації науководослідницької діяльності студентів - всеукраїнський. Він формує республіканський науковий простір, підструктурою якого виступає й кластер студентської науки. Цей щабель вможливлює для майбутнього вчителя географії широку сферу спілкування й обміну досвіду 3 однодумцями, тобто тими, які захоплюються тими самими дослідницькими проблемами в галузі педагогічних i географічних наук. Держава, віддаючи належне організації науководослідницької діяльності студентів, опікується проведенням у системі науково-організаційних заходів - всеукраїнських олімпіад i конкурсів творчих наукових робіт, проектів, інноваційних ідей i розробок, всеукраїнських студентських наукових конференцій, веб-форумів, тренінгів, практикумів; започатковує літні й зимові школи для молодих науковців; підтримує спеціальні періодичні та монографічні видання для студентів і молодих науковців. Заклад вищої освіти синхронізує свою діяльність згідно планів і програм, пропонованих Міністерством освіти і науки України, галузевих Міністерств і відомств, Національної Академії наук України, співвідносить iï iз приватними ініціативами осіб чи Фондів, які підтримують дослідницьку діяльність молодих науковців за допомогою іменних стипендій, грантів та інших матеріальних відзнак (Концепція та методологія..., 2016:69).

Нарешті, останній щабель системи науково-дослідницької діяльності студентів, який набирає обертів у останні роки у зв'язку 3 приєднанням України до європейського освітнього простору, а також із процесами глобалізації та інформатизації суспільства, це шостий - міжнародний рівень. Він характеризується тісною взаємодією закладу вищої освіти із закордонними освітніми закладами - партнерами i навіть 3 асоціаціями, міжнародними фондами. Багато вітчизняних університетів мають досвід проведення спільних студентських наукових конференцій, наукових стажувань і закордонних практик студентів. Усе більшого значення набувають студентські публікації, що індексуються в міжнародних наукометричних базах, конкурси наукових студентських проектів, грантові та рамкові програми за участю 
молодих науковців. Все більше розповсюджується програма Еразмус+. Такі заходи сприяють збагаченню наукової практики студентів, розширенню сфер міжнародної й міжкультурної взаємодії. Ті студенти, які займаються науково-дослідницькою роботою на міжнародному рівні, можуть бути без перебільшення названі молодими науковцями. Вони зазвичай мають сформовану професійну й наукову культуру, вільно володіють іноземними мовами, характеризуються розвиненою мотивацією до наукового пошуку.

\section{Висновки}

Наведені вище шість рівнів організації науково-дослідницької діяльності студентів - рівень первинних студентських наукових об'єднань навколо кафедральних тем, рівень структурного підрозділу університету (факультету чи інституту), рівень університету, регіональний, всеукраїнський та міжнародний рівні можуть бути вибудувані в ієрархічній послідовності і презентувати в своїй цілісності систему організації науково-дослідницької діяльності студентів. Кожен 3 розглянутих рівнів розрізняється один від іншого за функціональним призначенням, цільовими настановами, кількістю учасників, ступенем сформованості в студентів професійної та наукової культури, засобами керівництва. Кожен із них робить свій внесок і спрямований на вирішення конкретних завдань.

Ця система $є$ відкритою, вона перебуває у взаємозв'язку з іншими соціальними системами, головною метою їі функціонування $\epsilon$ виявлення талановитої молоді й залучення піi до науководослідницької діяльності, забезпечення наступності поколінь науковців у вищій школі, створення загальноуніверситетського наукового простору; підвищення грантової й публікаційної активності студентів, їх підготовка до інноваційної діяльності, розширення й розвиток професійних комунікацій між студентами на науковому рівні, розвиток студентського самоврядування й лідерства в науковій сфері, забезпечення розвитку міжнародного професійного співробітництва вчених, педагогів, студентів, практиків (Стромов, \& Сысоев, 2017:75).

Ці та інші заходи вможливлять перехід системи професійної підготовки майбутніх учителів географії на якісно новий рівень. 


\section{Література}

1. Вінник М. О. Інноваційні підходи до організації науководослідницької діяльності майбутніх інженерів-програмістів. Hayчные mpydbl SWorld. Иваново: Из-во ООО «Научный мир». 2016. Вып. 2 (43). С. 52-56.

2. Дьячек Т. П. Научно-исследовательская деятельность как средство интеграции университета в мировое образовательное пространство. Университет как системообразующий фактор региона и модели его управления: міжнародна науково-практична конференція (г. Тамбов, 29-31 октября 2003 г.). URL : http://socio. tamb.ru/6.htm.

3. Концепція та методологія реалізації науководослідницької діяльності суб'єктів навчально-виховного процесу університетів : монографія / кол. авт.; за ред. О. Г. Ярошенко. Київ : Інститут вищої освіти НАПН України, 2016. 178 с.

4. Лаврентьєва О. О. Розвиток методологічної культури майбутнього вчителя природничих дисциплін у процесі професійної підготовки: теоретико-методичний аспект : монографія. Київ: КНТ, 2014. 456 с.

5. Мієр Т. І. Дидактичні засади організації навчальнодослідницької діяльності молодших школярів: автореферат дис. ...д-ра пед. наук : 13.00.09 / Ін-т педагогіки. Київ, 2017. 44 с.

6. Нова українська школа: Концептуальні засади реформування середньої школи (Ухвалена рішенням колегії $\mathrm{MOH}$ 27.10.2016 р.) / упор.: Л. Гриневич, О. Елькін, С. Калашнікова, I. Коберник, В. Ковтунець, О. Макаренко, О. Малахова та ін. URL : http://mon.gov.ua/\%D0\%9D\%D0\%BE\%D0\%B2\%D0\%B8\%D0 \%BD\%D0\%B8\%202016/12/05/konczepcziya.pdf.

7. Стромов В. Ю., Сысоев П. В. Модель организации научно-исследовательской деятельности студентов в вузе. Bbcmеe образование сегодня. 2017. № 10. С. 75-82.

8. Топузов О. М., Самойленко В. М., Вішнікіна Л. П. Загальна методика навчання географії : підручник. Київ : ДНВП «Картографія», 2012. 512 с. 
Завальнюк О. С.

Організаційно-функціональна структура науково-дослідницької діяльності майбутніх учителів географії

\section{Анотація}

У статті розглянуто сутність і призначення, досліджено функціональну структуру науково-дослідницької діяльності майбутніх учителів географії.

Визначено, що науково-дослідницька діяльність майбутніх учителів є динамічним системним об'єктом, який може бути представлений у вигляді ієрархічно вибудованих рівнів організації, які розрізняються за цільовими настановами, способами наукового керівництва й кількістю залучених до цієї діяльності учасників.

3'ясовано, що фундаментом системи є підсистема навчально-дослідницької діяльності студентів, над яким надбудовуються шість рівнів організації. Це - рівень первинних студентських наукових об'єднань навколо кафедральних тем, рівень структурного підрозділу університету, рівень університету, регіональний, всеукраїнський та міжнародний рівні. Кожен 3 низ має свою специфіку відповідно до завдань професійної підготовки майбутніх учителів географії.

Ключові слова: науково-дослідницька діяльність студентів, зміст професійної підготовки майбутніх учителів географії, педагогічна система, організація науково-дослідницької діяльності.

Завальнюк Е. С.

Организационно-функциональная структура научноисследовательской деятельности будущих учителей географи

\section{Аннотация}

В статьи рассмотрены сущность и назначение, исследована функциональная структура научно-исследовательской деятельности будущих учителей географии. 
Определено, что научно-исследовательская деятельность будущих учителей является динамическим системным объектом, который может быть представлен в виде иерархически выстроенных уровней организации, различающиеся целевыми установкам, способами научного руководства и количеством привлеченных к этой деятельности участников.

Выяснено, что фундаментом системы является подсистема учебно-исследовательской деятельности студентов, над которым надстраиваются шесть уровней организации. Это уровень первичных студенческих научных объединений вокруг кафедральных тем, уровень структурного подразделения университета, уровень университета, региональный, всеукраинский и международный уровни. Каждый из них имеет свою специфику и соответствует задачам профессиональной подготовки будущих учителей географии.

Ключевые слова: научно-исследовательская деятельность студентов, содержание профессиональной подготовки будущих учителей географии, педагогическая система, организация научноисследовательской деятельности. 